"Przegląd Prawa Konstytucyjnego" Nr $3(15) / 2013$

\title{
Sprawozdanie
}

\section{Obchody Światowego Dnia Wyborów, Toruń, 7 lutego 2013 r.}

Postanowieniem uczestników Światowej Konferencji Urzędników Wyborczych zorganizowanej w 2005 r. w Siófok na Węgrzech pierwszy czwartek lutego został ustanowiony Światowym Dniem Wyborów (Global Elections Day). Termin ten został wybrany z uwagi na podpisanie wielu umów międzynarodowych z zakresu wyborów w tym dniu lub około tej daty. Święto to jest symbolem powszechnego udziału obywateli w wyborach. Corocznie $\mathrm{w}$ ramach jego obchodów w wielu państwach są organizowane wykłady i dyskusje na temat roli demokratycznych elekcji, sposobów motywowania partycypacji wyborczej czy upraszczania procedur głosowania.

Ogólnopolskie obchody - ósmego już - Światowego Dnia Wyborów, który przypadł w bieżącym roku na dzień 7 lutego, miały miejsce w Grodzie Kopernika. Zorganizowały je Państwowa Komisja Wyborcza, Krajowe Biuro Wyborcze oraz Centrum Studiów Wyborczych Uniwersytetu Mikołaja Kopernika w Toruniu. W ich programie znalazła się adresowana do młodzieży akcja Decyduje, więc głosuję! oraz szósta już prelekcja z cyklu wykładów im. Prof. Dr. Wacława Komarnickiego. W obu częściach uroczystości udział wzięli m.in.: Zsolt Szolnoki, Sekretarz Generalny Stowarzyszenia Europejskich Urzędników Wyborczych ACEEEO; Alexander Shlyk, doradca w Departamencie ds. Wyborów przy OBWE; przewodniczący centralnych komisji wyborczych: Zenonas Vaigauskas (Litwa), Arnis Cimdars (Łotwa), Branko Petrić (Bośnia i Hercegowina), sędzia Stefan J. Jaworski (Polska); ich zastępcy: Stanisław Vavilov (Rosja), Żanna Ywanowna Usenko-Czernaja (Ukraina), Marian Muhulet (Rumunia) oraz członkowie tych organów: Rashid Bekbasarov (Kirgistan), sędzia Maria Grzelka i sędzia Andrzej Mączyń- 
ski (Polska), a także Kazimierz W. Czaplicki, Sekretarz PKW, Szef Krajowego Biura Wyborczego.

Decyduje, więc głosuje to akcja przygotowana przez CSW UMK przy wsparciu Studenckiego Koła Naukowego Prawa Wyborczego „Elektor”. Jej założeniem, podobnie jak zrealizowanych w ubiegłych latach na Wydziale Prawa i Administracji UMK inicjatyw: Wyborczy pierwszy raz (2010) czy Młodzi głosuja! (dwukrotnie: 2011 r. i 2012 r.), było popularyzowanie wśród młodzieży wiedzy na temat istoty, funkcji i celów demokratycznych elekcji dla utwierdzania w nich postaw obywatelskich. Zaproszenie do udziału w akcji przyjęło niemal dwustu uczniów wraz z pedagogami ze szkół ponadpodstawowych z Torunia, Konina, Chojnic i Działdowa. Pierwszym akordem spotkania, które prowadził dr Bartłomiej Michalak (WPiSM UMK), była projekcja filmu pt. Podstawowe zasady prawa wyborczego, przygotowanego przez TV UMK według scenariusza i z udziałem studentów działających w Kole „Elektor”. W materiale opartym na konwencji telewizyjnego programu informacyjnego kolejni reporterzy poszukiwali odpowiedzi na pytania związane z naczelnymi zasadami prawa wyborczego. Zadawali je przechodniom i ekspertom, w których rolę wcielili się: prof. dr hab. Andrzej Sokala (Prorektor UMK ds. studenckich i polityki kadrowej, Kierownik CSW UMK), dr Marek Sobczyk (WPiA UMK) oraz dr Bartłomiej Michalak. Po zakończeniu emisji nagrania prof. dr hab. Andrzej Sokala opowiedział gościom o narodzinach idei stworzenia filmu. Wskazał, że jego premierowy pokaz inauguruje promocję projektu Szkoła wyborów, który realizować będzie CSW UMK oraz Koło „Elektor”, pod patronatem PKW. Przedsięwzięcie to ma na celu uruchomienie platformy edukacyjnej dla młodych wyborców, obejmującej w szczególności: stronę internetową, filmy edukacyjne, prezentacje multimedialne oraz broszury i scenariusze lekcji dla nauczycieli o tematyce wyborczej. Profesor Sokala poprosił zgromadzonych o opinie $\mathrm{w}$ sprawie projektu, aby ten $\mathrm{w}$ jak największym stopniu odpowiadał potrzebom uczniów, do których jest skierowany. Zarówno młodzież, jak i pedagodzy pozytywnie wypowiedzieli się w przedmiocie kompletu materiałów zaprezentowanych jako Lekcja $n r$ 1. Nauczyciele akcentowali, że ta unikatowa inicjatywa pomoże im w nowoczesny sposób przekazywać wiedzę w szkole. Uczniowie zapewniali, że multimedia lepiej do nich przemawiają niż tradycyjne lekcje. 
W dalszej części akcji Decyduję, więc głosuję! mgr Paweł Raźny zaprezentował wyniki ankiety, którą przeprowadziły CSW UMK i Elektor w dziesięciu szkołach z województw: kujawsko-pomorskiego, lubuskiego, pomorskiego, warmińsko-mazurskiego, wielkopolskiego oraz zachodniopomorskiego. Ogółem w badaniu wzięło udział 917 osób w wieku 16-21 lat. Ankieta dotyczyła stanu wiedzy młodych ludzi o wyborach i ich stosunku do głosowania. Z badania wynika, że $81,42 \%$ badanych niekorzystających dotąd z prawa głosu wyraziło pozytywny stosunek do głosowania i wolę udziału w nim w przyszłości. Młodzi wyborcy w większości korzystają z prawa głosu, ponieważ chca decydować (ogółem 42,31\%). Głównym powodem ich absencji jest z kolei brak potrzebnych informacji (46,43\%). Najczęściej wskazywanymi źródłami pozyskiwania wiedzy z zakresu prawa wyborczego były lekcje WoS-u (51,15\%). Tylko 38,27\% respondentów poprawnie nazwało najwyższy organ wyborczy w Polsce. Mniejszość badanych (24,43\%) poprawnie wyliczyło naczelne zasady prawa wyborczego.

Kolejnym punktem programu była debata młodzieży z ekspertami tematyki wyborczej. W tym charakterze wystąpili: Zsolt Szolnoki, Alexander Shlyk, Arnis Cimdars, sędzia Stefan J. Jaworski, minister Kazimierz W. Czaplicki, prof. dr hab. Andrzej Sokala i dr Jarosław Zbieranek (Instytut Spraw Publicznych). Pierwszy z ekspertów podziękował zgromadzonym uczniom za udział w obchodach Światowego Dnia Wyborów. Jego zdaniem partycypacja w tym wydarzeniu jest istotna, ponieważ może zaowocować późniejszym korzystaniem z praw wyborczych przez jego uczestników. Mówca dodał, że poczucie decydowania podczas oddawania głosu towarzyszy najsilniej właśnie najmłodszych wyborcom. Zsolt Szolnoki odniósł się również do kwestii nowych sposobów głosowania, w tym zwłaszcza za pomocą telefonu komórkowego. Sekretarz zauważył, że kolejne państwa umożliwiają oddawanie głosu w ten sposób właśnie z uwagi na ludzi młodych, dla których używanie urządzeń zaawansowanych technicznie jest codziennością. Arnis Cimdars podkreślił z kolei, że media zwykle koncentrują się na frekwencji jako najważniejszym mierniku demokracji. Tymczasem trzeba ją traktować jako jeden z wielu wyznaczników legitymizacji systemu politycznego. W jego opinii należy pobudzać naturalną partycypację poprzez utwierdzanie właściwego sposobu myślenia o wyborach, który skutecznie zmotywuje obywateli do głosowania. Alexander Shlyk 
przybliżył zebranym misję Biura Instytucji Demokratycznych i Praw Człowieka OBWE i zasady prowadzenia obserwacji wyborów na świecie. Sędzia Stefan J. Jaworski odpowiedział na pytanie dotyczące jednej z metod przeliczania głosów na mandaty, a minister Kazimierz W. Czaplicki skomentował wyniki ankiety, szczególnie zwracając uwagę na aspekt braku niezbędnych informacji jako jednej z przyczyn absencji wyborczej. Kwestię tę podjął również dr Jarosław Zbieranek, który zaznaczył, że głównym źródłem zdobywania wiedzy przez młodzież jest internet, stąd też inicjatywy takie jak Szkoła wyborów czy Obserwatorium prawa wyborczego, działające na portalu Facebook zasługują na uwagę i wsparcie. W dyskusji wziął udział także prof. dr hab. Andrzej Sokala, który odpowiedział na pytanie dotyczące realizacji zasady bezpośredniości w wyborach władz samorządu szkolnego. Ostatnim wydarzeniem akcji było ogłoszenie wyników i wręczenie nagród laureatom konkursów zorganizowanych przez CSW UMK. Wśród laureatów znaleźli się obok autorów plakatów, także twórcy haseł propagujących aktywny i świadomy udział młodych osób w wyborach: Weronika Kiedrowska (Młody głos, ważny głos!), Patrycja Goszczyńska (Polub Polskę - idź na wybory), Sylwia Nalikowska (Nie kuślosu, idźzagłosuj), Krystian Nita (Nie głosujesz - nie decydujesz!), Zuzanna Olszewska (Twój głos - Twoja Polska) oraz Tomasz Helwig (Wybory - I like it!).

Popołudniowym akcentem obchodów był tradycyjny już wykład im. Prof. Dr. Wacława Komarnickiego. Gospodarzem tej części spotkania był prof. dr hab. Andrzej Sokala, który po przywitaniu gości oddał głos sędziemu Stefanowi J. Jaworskiemu. Przewodniczący PKW odczytał treść uchwały podjętej przez Państwową Komisję Wyborczą w dniu 7 stycznia 2013 r., na mocy której Centrum Studiów Wyborczych UMK zostało wyróżnione medalem honorowym Iudices electionis custodes za wkład w rozwój demokratycznego prawa wyborczego Rzeczypospolitej oraz w popularyzację znaczenia praw wyborczych w społeczeństwie obywatelskim i w działania edukacyjne wśród młodzieży. Następnie o tym, że inicjatywy podejmowane przez odznaczoną jednostkę wspólnie z najwyższym organem wyborczym w Polsce są istotne także dla Wydziału Prawa i Administracji UMK w Toruniu, zapewnił dr Mikołaj Święcki, jego Prodziekan ds. Kształcenia i Organizacji, który za dotychczasową współpracę wręczył sędziemu Stefanowi J. Jaworskiemu pamiątkowy medal Wydziału. 
W dalszej części głos zabrał Zsolt Szolnoki, który wygłosił wykład na temat: Monitoring of Elections. Prelegent rozpoczął od stwierdzenia, że każde wybory opierają się na zaufaniu i pewności, a obserwowanie ich przebiegu niewątpliwie te wartości wspiera. W jego opinii obywatele mają prawo do wolnych i uczciwych elekcji organizowanych w stałych odstępach czasu (free, fair and periodic elections) urzeczywistniających zasady: powszechności, równości (universal and equal suffrage) i tajnego głosowania (secret ballot). Mówca zaznaczył, że rozumienie obserwacji (observation) różni się od rozumienia pojęcia nadzoru (supervision). Termin wskazany jako pierwszy oznacza wyłącznie monitorowanie wyborów, które nie zakłada ingerowania $\mathrm{w}$ ich przebieg, gdyż ten element zawiera się w definicji nadzoru. Podkreślił, że misje obserwacyjne można podzielić na: krajowe i międzynarodowe. W przypadku misji krajowych ich organizatorami są przeważnie aktywiści partii politycznych, którzy formułują oceny działania systemu wyborczego, aby kwestionować wynik elekcji. Obserwacje te nie muszą jednak zawsze przyjmować charakteru politycznego. Zdarzają się sytuacje, gdy monitoring krajowy prowadzą organizacje pozarządowe bez konotacji partyjnych. Z kolei obserwacje międzynarodowe prowadzą organizacje rządowe i pozarządowe lub państwa, które otrzymają zaproszenie do takiej działalności od władz innych krajów. Mogą one trwać od kilkudziesięciu do kilkuset dni, a spuścizną po nich są raporty podsumowujące wyniki monitoringu. Prelegent scharakteryzował działalność w tym zakresie: UE, Rady Europy, ODHIR OBWE oraz ACEEEO, z którego się wywodzi. W ostatniej części referent stwierdził, że dokonanie wyboru modelu organizacji dla konkretnej misji obserwacyjnej jest trudne. Decyzje w przedmiocie ustalenia jej zakresu temporalnego, osobowego i przedmiotowego podejmuje się po przeprowadzeniu wstępnej oceny warunków panujących w danym systemie politycznym. Składa się ona $\mathrm{z}$ analizy środowiska prawnego, zakresu przestrzegania praw człowieka i możliwości implementacji przez obserwatorów skutecznych kanałów komunikacyjnych od rządzących po uczestników wyborów. Wygłoszony wykład wywołał dyskusję. Wzięli w niej udział przedstawiciele toruńskiego Wydziału Prawa i Administracji: prof. dr hab. Bożena Gronowska i prof. dr hab. Zbigniew Witkowski, którzy zapytali odpowiednio o opinię prelegenta na temat możliwości stworzenia uniwersalnego zespołu wytycznych dla obserwacji wyborów w państwach na całym świecie i w przedmiocie zasadno- 
ści utrzymania ciszy wyborczej. Spotkanie zakończył prof. dr hab. Andrzej Sokala, który podziękował mówcy za interesujące wystąpienie, a gościom za wysłuchanie prelekcji. Korzystając z okazji, gospodarz zaprosił wszystkich obecnych na przyszłoroczny wykład im. Prof. Dr. Wacława Komarnickiego.

Tegoroczne obchody Światowego Dnia Wyborów należy zaliczyć do przedsięwzięć udanych. Zainteresowanie akcją Decyduję, więc głosuję! oraz wysokie oceny projektu Szkoła wyborów bez wątpienia świadczą o potrzebie podejmowania takich inicjatyw. Szósty z kolei wykład imienia słynnego polskiego prawnika, który zgromadził międzynarodowe grono słuchaczy, jak zwykle stał się okazją do omówienia aktualnych spraw związanych z procedurą wyborczą, które znajdują się w optyce zainteresowania zarówno nauki, jak i praktyki. Spotkania takie jak to są szczególnie cenne, zwłaszcza w kontekście doskonalenia rozwiązań prawa wyborczego.

Paweł Raźny

Centrum Studiów Wyborczych Uniwersytetu Mikołaja Kopernika w Toruniu 